\title{
Preliminary laboratory thermo-hydro-mechanical characterization of Opalinus clay
}

\author{
A.M. Tang \& Y.-J. Cui \\ Laboratoire Navier/CERMES, Ecole des Ponts ParisTech, Marne-la-Vallée, France
}

\begin{abstract}
Argillite is being considered as a possible host rock for geological radioactive waste disposal in several countries. In the present work, Opalinus clay, taken from the Mont Terri Rock laboratory (Switzerland) was tested. A triaxial compression test was performed under saturated conditions. It was observed that preparing a specimen for triaxial test (38 mm in diameter and $76 \mathrm{~mm}$ in height) may induce certain damage on the material. In addition, when saturating the specimen under its in situ stress $(2 \mathrm{MPa})$, a volumetric swell of $1.2 \%$ occurred. The swelling process continued even after $200 \mathrm{~h}$ of saturation. The results suggest that the variability of mechanical properties of Opalinus clay obtained from existing studies is related to the damage induced during the preparation of specimens on the one hand and the saturation on the other hand. Secondly, a possible effect of heating (which would be generated by the radioactive waste canister in the conditions of waste disposal) on the mechanical behaviour was also tested. A soil specimen, having a suction of $39 \mathrm{MPa}$ was subjected to a heating/cooling cycle (temperature increased from 25 to $60^{\circ} \mathrm{C}$ and then decreased to $25^{\circ} \mathrm{C}$ ) under a low confining pressure $(0.1 \mathrm{MPa})$. The results show that heating induced first a thermal dilation. When the temperature was maintained at $60^{\circ} \mathrm{C}, \mathrm{a}$ decrease of the soil volume was observed. The subsequent cooling induced a decrease of the soil volume with the same thermal dilation coefficient obtained during the heating. The thermal behavior of Opalinus clay (thermal dilation and then contraction during heating) is then similar to that usually observed on clays. Further studies on the temperature effects are needed to clarify this behaviour.
\end{abstract}

SUBJECT: Rock material and rock mass property testing (laboratory and in situ)

KEYWORDS: lab testing; nuclear repository; weak rock

\section{INSTRODUCTION}

In the concept of geological radioactive waste disposal, argillite is being considered as a possible host rock in various countries such as France and Switzerland. This material is chosen thanks to its extremely low permeability that is required to limit the transfer of radioactive elements from the waste package towards the environment.

During the construction and exploitation phase of the radioactive waste disposal, the host rock will be subjected to various thermo-hydro-mechanical loadings. The mechanical loading can be induced by the excavation of the tunnel or the installation of engineered barriers. The hydrological loading can correspond to the drying process on the inner wall of the tunnel during the excavation and the resaturation process by water coming from the aquifer after the closure of the tunnel. And finally, thermal solicitation comes from the heat emitting from the radioactive waste packages. On one hand, the behavior of the host rock under each solicitation is important for the design of such storage, on the other hand, the behavior under the coupled thermohydro-mechanical solicitations is also needed to be well understood.

In the present work, some preliminary results on the laboratory thermo-hydro-mechanical characterization of Opalinus clay are presented. The material is one of the argillites being studied in several research projects in
Europe in the context of geological radioactive waste disposal.

\section{MATERIAL STUDIED}

The soil cores of Opalinus clay were taken from the Mont Terri rock laboratory in Switzerland (Bossart \& Thury, 2007). Several research projects have been and are being performed in the rock laboratory in the context of the Mont Terri Project which is an International Research Project for the Hydro-geological, Geochemical and Geotechnical Characterization of a Clay Formation (Opalinus Clay). The main properties of Opalinus clay can be found in the work of Corkum \& Martin (2007).

In Table 1, the typical mineral composition of Opalinus clay is presented. It can be seen that this material is composed of $65 \%$ clay particles consisting mostly of kaolinite and illite. The non-clay minerals consist mainly of quartz (20\%) and calcite $(7 \%)$. The index properties are presented in Table 2 . With a liquid limit of $38 \%$ and a plasticity index of $15 \%$, this material can be classified as Clay of Medium plasticity (CI) following the Unified Soil Classification System. The initial water content is relatively low $(6 \%)$ corresponding to a low value of porosity (12\%). 
Table 1. Typical mineral composition of Opalinus clay (after Corkum \& Martin, 2007).

\begin{tabular}{llll}
\hline Mineral & $(\%)$ & $\begin{array}{l}\text { Mineral } \\
\text { (non-clay) }\end{array}$ & $(\%)$ \\
\hline Kaolinite & 30 & Quartz & 20 \\
$\begin{array}{l}\text { Illite } \\
\begin{array}{l}\text { Illite-smectitte } \\
\text { (mixed layer) }\end{array}\end{array}$ & 17 & Calcite & 7 \\
Chlorite & 10 & Feldspars & 3 \\
\hline
\end{tabular}

Table 2. Index properties of Opalinus clay (after Corkum \& Martin, 2007).

\begin{tabular}{llll}
\hline Property & Value & Property & Value \\
\hline $\begin{array}{l}\text { Bulk density } \\
\left(\mathrm{Mg} / \mathrm{m}^{3}\right)\end{array}$ & 2.45 & $\begin{array}{l}\text { Water content } \\
(\%)\end{array}$ & 6 \\
Liquid limit $(\%)$ & 38 & Porosity (\%) & 12 \\
Plastic limit (\%) & 23 & Void ratio (-) & 0.19 \\
Plasticity index (\%) & 15 & & \\
\hline
\end{tabular}

\section{EXPERIMENTAL METHODS}

\subsection{Triaxial compression test}

In order to investigate the mechanical properties of the material, triaxial compression test was performed on resaturated soil specimens. A high-pressure triaxial cell was used (for the details of the experimental setup, see Cui et al., 2009). This system allow application of the confining pressure up to $64 \mathrm{MPa}$, the back pressure up to $4 \mathrm{MPa}$, and the axial stress up to $100 \mathrm{MPa}$.

From a soil core having a diameter of $90 \mathrm{~mm}$ and a length of $1000 \mathrm{~mm}$, two methods were used to prepare triaxial specimen of $38 \mathrm{~mm}$ in diameter and $76 \mathrm{~mm}$ high. Note that the bedding orientation is perpendicular to the axis of the core. The first method consists of drill-coring directly inside the large core. To avoid the reaction between the Opalinus clay with the usual cooling fluids, such as water or oil, highpressure air was used to cool down the specimen during coring. Finally, this method was found not adapted to the material because the specimen was separated into several disks after drilling. Such phenomenon of core disking has been also observed by Corkum \& Martin (2007) on larger cores. The second method was then used to prepare the soil specimen. That consists of cutting the large core by thaw into a smaller prism and then finalize by file in order to have a cylinder of $38 \mathrm{~mm}$ in diameter and $76 \mathrm{~mm}$ high.

After the installation of the soil specimen inside the triaxial cell, a confining pressure of $2 \mathrm{MPa}$ was applied. This value is close to the minimum principal stress of Opalinus clay in the Mont Terri rock mechanics laboratory (after Blümling et al., 2007). The soil specimen was then resaturated under this effective confining pressure by increasing in steps of $200 \mathrm{kPa}$ both confining pressure and back pressure. The re-saturation process was finished when the volume change of the soil reached the stabilization. After Delage et al. (2007), resaturate the over-consolidated clayey soil under its in situ stress avoid swelling upon wetting. This swelling may induce significant changes in the microstructure of soil and thus modify its hydromechanical properties.

\subsection{Heating/Cooling test under suction controlled conditions in isotropic cell.}

This test aims at investigating the thermal volume change behavior of Opalinus clay under suction controlled and isotropic pressure conditions. The isotropic cell developed by Tang et al. (2007) for studying the thermo-mechanical behavior of unsaturated expansive clays was used. The basic scheme of the cell is presented in Figure 1. The soil specimen ( $80 \mathrm{~mm}$ in diameter, $10 \mathrm{~mm}$ high) is sandwiched between two ceramic porous stones that are built in two metallic plates. Small holes drilled on the lower plate allow moisture exchanges between soil specimen and the chamber below. The relative humidity of air in this chamber is controlled by a glass cup containing saturated saline solution. This system allows controlling the soil suction during the test. To control the temperature, the cell is immersed in a temperature-controlled bath. The isotropic pressure applied on the soil specimen is controlled by a volume/pressure controller. This later is equally used to monitor the soil volume change from the water exchange with the cell.

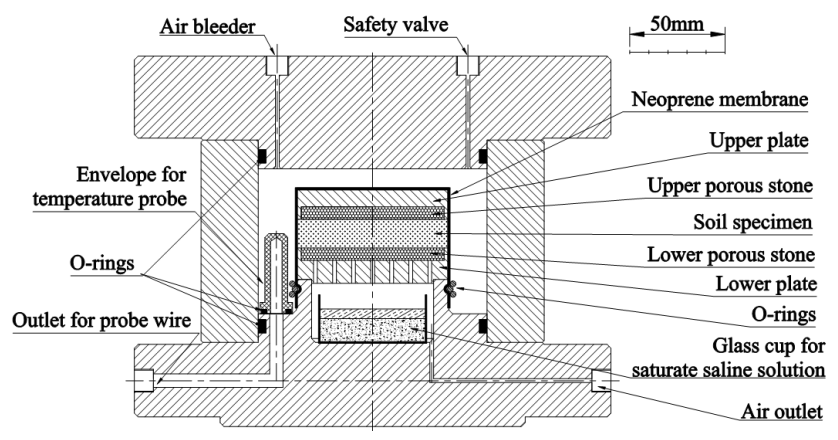

Figure 1. Basic scheme of the suction-temperature controlled isotropic cell. (after Tang et al., 2007)

\section{EXPERIMENTAL RESULTS}

\subsection{Triaxial compression test}

In Figure 2, the soil volume change during the re-saturation phase is presented. Note that the confining pressure was equal to $2 \mathrm{MPa}$ during this phase. The results show a volumetric swelling of $1.2 \%$ during this re-saturation phase. It can be also observed that the time required to reach this value is relatively long, $250 \mathrm{~h}$. In addition, the swelling seems not to reach the stabilization even after such a long period.

The swelling behavior of Opalinus clay observed during the re-saturation is in agreement with other observations in the literature review. Horseman et al. (2007) observed a volumetric swelling strain of $2.9 \%$ after $200 \mathrm{~h}$ when immersing a $40 \mathrm{~mm}$ cube of Opalinus clay in distilled water. Zhang et al. (2007) obtained also $1 \%$ of volumetric swelling strain after $200 \mathrm{~h}$ when applying $4 \mathrm{MPa}$ back pressure from one side of the specimen in a triaxial cell under $5 \mathrm{MPa}$ confining pressure. When the back pressure was applied on the two sides of the soil specimen, an additional swelling strain of $0.8 \%$ was observed. 


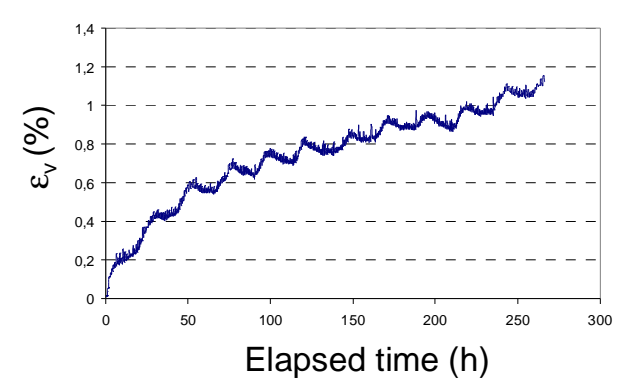

Figure 2. Swelling strain during the resaturation phase under $2 \mathrm{MPa}$ confining pressure.

After the resaturation, shearing was performed under an effective confining pressure of $2 \mathrm{MPa}$. A constant stress rate of $0.3 \mathrm{kPa} / \mathrm{min}$ was applied. This low rate was chosen to ensure the drained conditions of the test. In Figure 3, the changes of deviator stress, $q$, and the axial strain, $\varepsilon_{a}$, versus time are plotted. The results show that the axial strain increases slowly during the first hours. It increases linearly with time in the period between 200 and $600 \mathrm{~h}$. When the deviator stress reached $11 \mathrm{MPa}$, the axial strain increases abruptly with time, indicating that the sample reached failure.

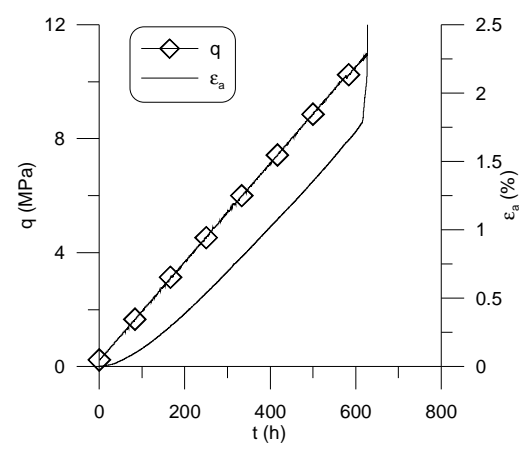

Figure 3. Deviator stress and axial strain versus time during shearing.

The results of the triaxial compression test are shown in Figure 4 . The $q-\varepsilon_{\text {a }}$ plot shows that the maximal deviator stress under an effective confining pressure is equal to $11 \mathrm{MPa}$ and failure is reached at $\varepsilon_{a}$ equals $1.8 \%$. This behavior is in agreement with the results obtained by Blümling et al. (2007) and Naumann et al. (2007). The volumetric behavior was measured with two systems: (1) fluid exchange by the confining pressure controller; (2) pore-water exchange by the back pressure controller. The results obtained by the two systems are different. With the measurement by the back-pressure system, a contracting behavior was observed and the volumetric strain reached $1 \%$ before failure. With the measurement by the confiningpressure system, the contraction was significantly higher. Even if triaxial tests are usually performed on Opalinus clay, available data on the volumetric change during shearing are still rare. This lack of data could be related to the experimental difficulties when studying such a material.

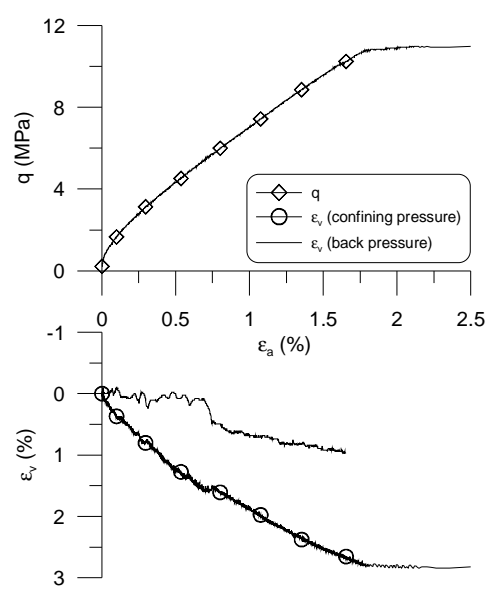

Figure 4. Deviator stress and volumetric strain versus axial strain during shearing.

\subsection{Thermal volumetric behavior of unsaturated Opalinus clay}

A heating-cooling test was performed at a suction controlled at $39 \mathrm{MPa}$ and a confining pressure of $2 \mathrm{MPa}$. Before the installation of the sample inside the cell, suction was imposed to the soil specimen using the vapor equilibrium technique (see Tang \& Cui, 2005). The soil mass reached the equilibrium after 40 days. Once installed in the isotropic cell described in Figure 1, a confining pressure of $0.1 \mathrm{MPa}$ was applied. The volume change of soil during this phase was considered negligible. The initial temperature of the cell was fixed at $25^{\circ} \mathrm{C}$.

A heating-cooling cycle was then applied in these conditions. The results are shown in Figure 5. From $25^{\circ} \mathrm{C}$, the temperature was increased in steps to $37^{\circ} \mathrm{C}, 61^{\circ} \mathrm{C}$ and then decreased to $25^{\circ} \mathrm{C}$. The record on the volume of fluid in the volume/pressure controller shows that heating induced first an increase of $\mathrm{d} V$. This increase corresponds to the volume of water expelled from the cell because of the thermal dilation of water in the cell and the soil specimen. Once the temperature reached the stabilization, $\mathrm{d} V$ decreases slightly. This diminution can be then attributed to the volume change of soil (contraction in this case).

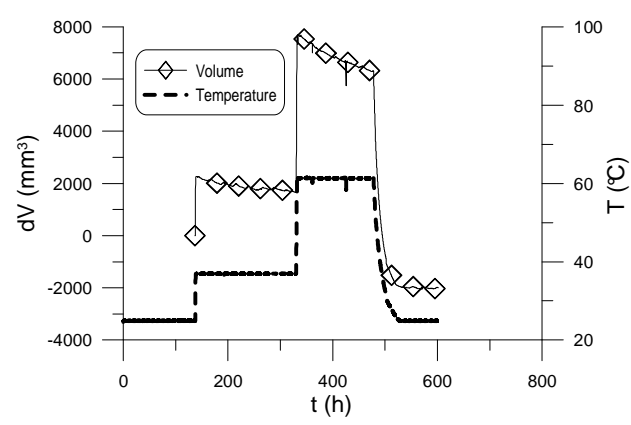

Figure 5. Change of volume of confining-pressure fluid and temperature versus time during the heating-cooling test.

The volume change of the soil specimen was determined from the results shown in Figure 5 and from the calibration curve obtained on a metallic specimen (see Tang et al., 2007 for more details). The results are shown in Figure 6. On a whole, heating induced an immediate dilation followed by a 
contraction when temperature is maintained constant. The relationship between temperature and volumetric strain is almost linear when heating from $37^{\circ} \mathrm{C}$ to $61{ }^{\circ} \mathrm{C}$ and when cooling. The volumetric thermal dilation coefficient calculated from these slopes is equal $5 \times 10^{-4}{ }^{\circ} \mathrm{C}^{-1}$. This coefficient is similar to that obtained previously in other studies. Munoz et al. (2009) obtained a linear thermal dilation coefficient of $1.35 \times 10^{-5}{ }^{\circ} \mathrm{C}^{-1}$, Gens et al. (2007) reported a value of $2.6 \times 10^{-5}{ }^{\circ} \mathrm{C}^{-1}$.

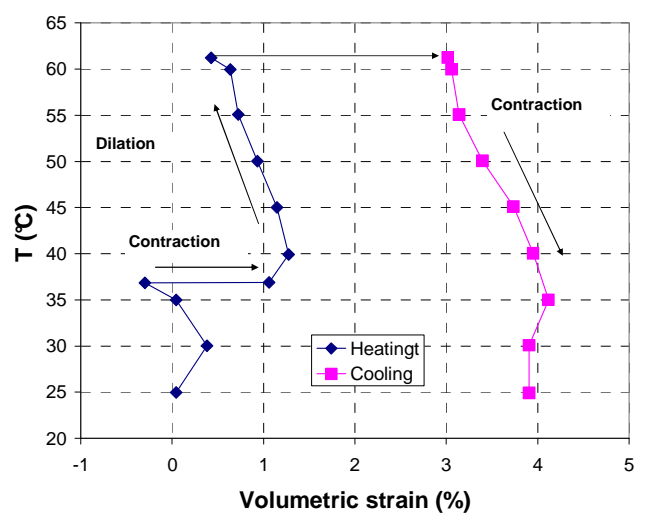

Figure 5. Soil volume change during the heating-cooling test.

The thermal contraction was observed on plastic clay (Cui et al., 2009) or compacted soils (Tang et al., 2008) and usually explained by a plastic deformation induced by the collapse of macro-pores (Tang \& Cui, 2009). This concept is no longer valid for Opalinus clay since the microstructure of this material is relatively dense (Bock et al., 2006). The thermal contraction was equally observed by Zhang et al. (2007) and Jobmann \& Polster (2007). Jobmann \& Polster (2007) explained the contraction by the release of pore water during heating.

\section{CONCLUSION}

Some experimental results on the thermo-hydro-mechanical behavior of Opalinus clay are presented. It appeared that it is difficult to prepare specimens for triaxial test due to the disking phenomenon. In addition, swelling of $1.2 \%$ was observed during the re-saturation phase under in situ stress conditions (2MPa of confining pressure). A contracting behavior was observed during shearing under these conditions. In the case of isotropic compression test at unsaturated state, heating under low pressure induced an immediate thermal dilation followed by a thermal contraction. The contraction is to be linked to the release of pore water.

\section{REFERENCES}

Blumling, P., Bernier, F., Lebon, P., Martin, D. (2007). The excavation damaged zone in clay formations timedependent behaviour and influence on performance assessment. Physics and Chemistry of the Earth 32(8-14), 588-599.

Bock, H., Blumling, P., Konietzky, H. (2006). Study of the micro-mechanical behaviour of the Opalinus Clay: an example of co-operation across the ground engineering disciplines. Bull Eng Geol. Env. 65(10), 195-207.

Bossart, P., Thury, M. (2007). Research in the Mont Terri Rock laboratory: Quo vadis? Physics and Chemistry of the Earth 32(1-7), 19-31.

Corkum, A.G., Martin, C.D. (2007). The mechanical behaviour of weak mudstone (Opalinus Clay) at low stresses. International Journal of Rock Mechanics \& Mining Sciences 44(10), 196-209.

Cui, Y.J., Le, T.T., Tang, A.M., Delage, P., Li, X.L., 2009. Investigating the time-dependent behaviour of Boom clay under thermo-mechanical loading. Géotechnique 59 (4), $319-329$

Delage, P., Le, T. T., Tang, A. M., Cui, Y. J., Li, X. L., 2007. Suction effects in deep Boom Clay block samples. Géotechnique 57 (2), 239-244.

Gens, A., Vaunat, J., Garitte, B.,Wileveau, Y. (2007). In situ behaviour of a stiff layered clay subject to thermal loading: observations and interpretation. Géotechnique 57(2), 207-228.

Horseman, S.T., Harrington, J.F., Noy, D.J. (2007). Swelling and osmotic flow in a potential host rock. Physics and Chemistry of the Earth 32(1-7), 408-420.

Jobmann, M., Polster, M. (2007). The response of Opalinus clay due to heating: A combined analysis of in situ measurements, laboratory investigations and numerical calculations. Physics and Chemistry of the Earth 32(814), 929-936.

Munoz, J.J., Alonso, E.E., Lloret, A. (2007).Thermohydrolic characterization of soft rock by means of heating pulse tests. Géotechnique 59(4), 293 - 306.

Naumann, M., Hunsche, U., Schulze, O. (2007). Experimental investigations on anisotropy in dilatancy, failure and creep of Opalinus Clay. Physics and Chemistry of the Earth 32(8-14), 889-895.

Popp, T., Salzer, K. (2007). Anisotropy of seismic and mechanical properties of Opalinus clay during triaxial deformation in a multi-anvil apparatus. Physics and Chemistry of the Earth 32(8-14), 879-888.

Tang, A. M., Cui, Y. J., 2005. Controlling suction by the vapour equilibrium technique at different temperatures and its application in determining the water retention properties of MX80 clay. Canadian Geotechnical Journal 42 (1), 287-296.

Tang, A.M., Cui, Y.J., 2009. Modelling the thermomechanical behaviour of compacted expansive clays. Géotechnique 59 (3), 185-195.

Tang, A. M., Cui, Y. J., Barnel, N., 2007. A new isotropic cell for studying the thermo-mechanical behavior of unsaturated expansive soil. Geotechnical Testing Journal 30 (5), $341-348$.

Tang, A. M., Cui, Y. J., Barnel, N., 2008. Thermomechanical behaviour of a compacted swelling clay. Géotechnique 58 (1), 45-54.

Zhang, C. L., Rothfuchs, T., Su, K., Hoteit, N. (2007). Experimental study of the thermo-hydro-mechanical behaviour of indurated clays. Physics and Chemistry of the Earth 32(8-14), 957-965. 